PiotR L. WiLCZYŃSKI

Uniwersytet Pedagogiczny, Kraków

\title{
Innowacje w zbrojeniach i obronności jako katalizator przemian technologicznych
}

\author{
BADANIA TECHNOLOGII WOJSKOWYCH W HISTORII
}

I ICH WPŁYW NA ŻYCIE CODZIENNE SPOŁECZEŃSTW

Wynalazczość w ciągu ostatnich 200 lat popchnęła znacznie ludzkość w rozwoju. Jeszcze w tamtych czasach dla niektórych elektryczność była tożsama z magią, a życie codzienne nie odbiegało zbytnio od trybu ustalonego wielowiekową tradycją. Zmiany technologiczne zachodziły wyraźnie również w kwestii zbrojeń i obronności. Zmieniały sie strategie wojenne, sztuka operacyjna, oraz taktyka poszczególnych armii (Wilczyński 2010, s. 101-120). Mniej innowacyjne ulegały stosującym korzystniejsze rozwiązania technologiczne w uzbrojeniu, sprzęcie, czy medycynie wojskowej oraz inżynierii czy naukach społecznych. Wprowadzało to konieczność inwestowania w nową myśl techniczną, przynajmniej z punktu widzenia bezpieczeństwa narodowego. Głowy jednostek politycznych, które tego nie rozumiały, narażały swoich obywateli na niebezpieczeństwa wynikające z przewagi technologicznej obcych. W czasach napięcia politycznego zwykło się uznawać te inwestycje za tak zwany wyścig zbrojeń. O ile przyrost ilościowy armii można tak nazwać, to rozwój techniki wojskowej opisany jest tym terminem bardzo trafnie.

Wiele osób uważa armie świata za wielkiego beneficjenta nauki, czerpiącego korzyści $\mathrm{z}$ rozwoju naukowego. Jest w tym wiele prawdy, jednak zupełnie inne światło rzuca przeanalizowanie czasu gdy powstało najwięcej wynalazków czyli XIX i XX wieku. Zważywszy na termin powstawania najważniejszych wynalazków, nie tylko wojskowych, ale wszystkich, zwraca uwagę nierównomierne rozłożenie ich w czasie (rys. 1). Jak się okazuje ich powstawanie skorelowane jest z okresami wielkich kryzysów gospodarczo-politycznych i przemian na arenie międzynarodowej.

Spore zmiany nastąpiły w czasie liberalizacji gospodarki merkantylistycznej. To wtedy Adam Smith i jego wiekopomne dzieło „O bogactwie narodów” mogli się cieszyć ze wprowadzania w życie swoich idei, kończąc długi okres marazmu i zastoju gospodarczego w Europie. Liberalizacja gospodarki przyczyniła się do rozwoju przemysłu, głównie w Wielkiej Brytanii, gdzie wprowadzono maszynowe przędzalnie bawełny, technologie wal- 
cowania żelaza, prowadzącą do budowania mocnych żeliwnych konstrukcji, na przykład mostów. Rosnące zapotrzebowanie na węgiel i żelazo doprowadziło tam także do wprowadzania pierwszych maszyn parowych służących w kopalniach. Uprzemysłowienie było znacznym krokiem w rozwoju również dla armii. Mocarstwa ówczesne zaczęły na masową skalę rozwijać armie, których uzbrojenie stało się dzięki nowym technikom produkcji o wiele tańsze niż wcześniej, a także pojawiło się doskonalsze uzbrojenie. Broń palna stała się powszechna, przez co formacje piechoty zaczęły wypierać kawalerię, a dużego znaczenia zaczęło nabierać zastosowanie udoskonalonej artylerii, w czym doskonały okazał się potem późniejszy cesarz Francuzów Napoleon Bonaparte. Nowinki techniczne dotarły także do marynarki wojennej, gdzie zaczęto budować coraz szybsze i zwrotniejsze okręty, uzbrojone w coraz większą liczbę dział. Niejeden okręt liniowy, z trzema pokładami dział, miał ich więcej niż nie jedna armia. Ostatnie trzydziestolecie XVIII wieku to okres wzmacniania gospodarczej i politycznej siły krajów europejskich, który w świecie nauki pozostawił jedynie nieliczne wynalazki jak balon napełniony wodorem, czy adaptacja maszyny parowej do celów napędowych na statkach (Parker 1988, s. 223 i in.).

Rozwój przemysłu wyznaczył także nowy trend społeczny. Powstanie klasy robotniczej doprowadziło w połączeniu z ideami liberalnymi do krwawej rewolucji oraz wojen napoleońskich. Ten okres zamętu okazał się obfity w wynalazki. Zaadaptowano dalekowschodni system sygnalizacyjny, znany nam pod nazwą semafora, udoskonalone zostały maszyny pracujące w przemyśle lekkim, postęp nastąpił w hydraulicznych rozwiązaniach maszynerii, wprowadzono druk litograficzny, odkryto elektryczność, wynaleziono śruby oraz fotografię, zbudowano pierwszy parowóz oraz odkryto właściwości morfiny. $\mathrm{Na}$ arenach wojennych pojawiły się wtedy pierwsze fregaty napędzane jednocześnie siłą wiatru i pary, zaś w bitwach lądowych uznanie zyskały nowoczesne karabiny i armaty gwintowane, rażące z większą celnością i na większe dystanse. Wprowadzono także nowe rozwiązania w strategii (jak system dywizyjny) czy w taktyce (jak tyralierę).

Czy to kwestia wykrwawienia całych narodów, czy konieczności odbudowy gospodarki sprawił, że okres po kongresie wiedeńskim, kończącym wojny napoleońskie nie obfitował w nowe technologie. Dopiero w przededniu Wiosny Ludów wprowadzono w budownictwie udoskonalony cement zwany portlandzkim, stosowany do dziś. Pojawiła się wtedy także w fizyce teoria, której efektem był elektromagnes. Czasy tak zwanej Wiosny Ludów były z kolei bardzo obfite w udoskonalenia i innowacje. Przy czym wynalazki powstawały już nie tylko w Europie. Znaczna ich część została wprowadzona w Stanach Zjednoczonych. Do najważniejszych wynalazków europejskich zaliczyć należy zapałki, elektrolizę, rower, dwusuw parowy powstałe na Wyspach Brytyjskich, oraz aluminium, dynamo, telegraf i transformator odkryte w pozostałych krajach. W USA w owym czasie wynaleziono maszynę do pisania, rewolwer, kompas słoneczny, alfabet Morse’a oraz gumę. Do owych wynalazków można zaliczyć dwa spóźnione nieco patenty, lecz których podstawy były wypracowane jeszcze w czasie Wiosny Ludów - w drugiej połowie lat 40-tych XIX wieku. Chodzi o dynamit i konwertor Bessemera do produkcji stali. W latach sześćdziesiątych wynaleziono jedynie dwie istotne rzeczy - wieloosobową łódź podwodną, oraz sporządzono tablicę okresową pierwiastków. Czasy Wiosny Ludów to także czas wprowadzenia nowoczesnych wynalazków w armiach. Najważniejszym chyba była odpowiedź na stosowanie fosforowych pocisków zapalających wobec których drewniane okręty były bezbronne. W odpowiedzi zaczęto stosować metalowe poszycia, bądź to z brązu, bądź z mosiądzu lub żelaza a następnie stali. 


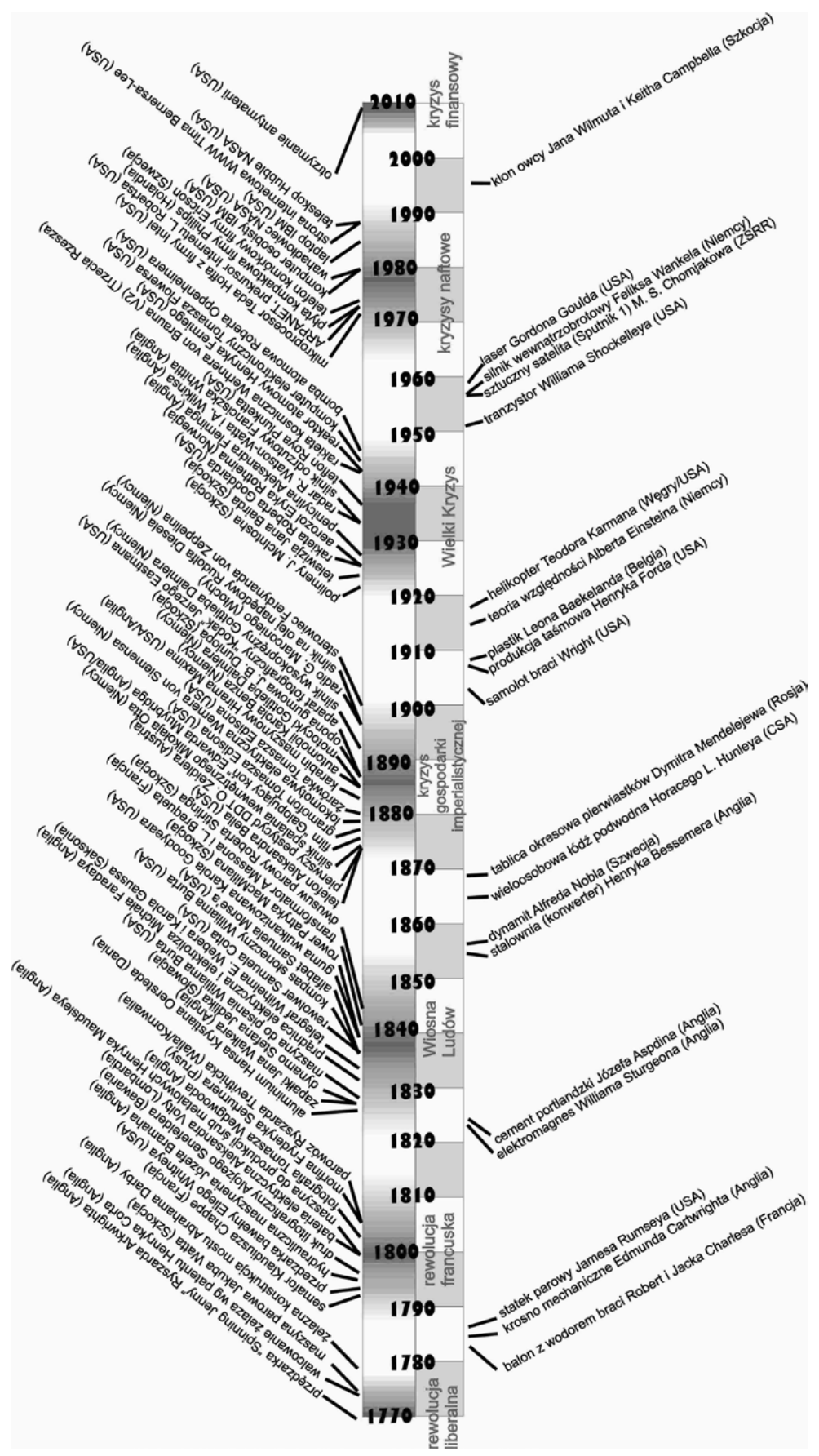

Rys. 1. Największe wynalazki na osi czasu od 1770 roku (opr. Piotr L. Wilczyński i Witold J. Wilczyński) 
Udoskonalano broń palną, wprowadzano nowe formacje. Przede wszystkim jednak usprawniona została dzięki telegrafowi i kolei łączność.

W następnych latach nastał okres prosperity. Pod koniec XIX wieku nastąpiło przesilenie, a od zachodu po wschód przesunęły się fale protestów i lokalnych wojen. W owym czasie znów można było zaobserwować falę wynalezionych innowacji. W Europie zastosowano po raz pierwszy pestycydy DDT, silniki spalinowe i wysokoprężne, lokomotywy elektryczne, auta i motocykle, opony, radio oraz sterowce. W Ameryce opracowano również kilka istotnych dla ludzkości patentów. Do najważniejszych można zaliczyć telefon, film, gramofon, żarówkę, aparat fotograficzny, czy już na początku XX wieku - samolot. Do najważniejszych innowacji w zbrojeniach owych czasów, które zrewolucjonizowały pole bitwy należały karabiny maszynowe oraz zastosowanie sterowców. Wynalazki tej epoki przyczyniły się do powstania wojsk pancernych i lotnictwa w czasach I wojny światowej, która stanowi koniec wielkich imperiów XIX wieku. Jedne z nich upadły, pozostałe zmieniły swe społeczne oblicza (Liebfeld 1975, s. 551 i n.). Dogasanie idei imperializmu trwało zadziwiająco długo mimo bardzo chwytliwych ówcześnie haseł socjalizmu i komunizmu. Również w czasie trwania w Europie zawieruchy społeczno-politycznej, wynalazczość trwała. Na drugie dziesięciolecie XX wieku datuje się skonstruowanie linii produkcyjnej Forda oraz pierwszego helikoptera, wynalezienie plastiku, czy opracowanie teorii względności.

Okres powojennego względnego spokoju nie trwał długo. Już w latach dwudziestych w Stanach Zjednoczonych, a nieco później w Europie dał o sobie znać Wielki Kryzys zakończony II wojną światową. W tym czasie również można zaobserwować przyspieszenie w rozwoju technologicznym. W USA zbudowano pierwszą rakietę, odkryto właściwości teflonu, a pod koniec wojny zbudowano reaktor i bombę atomową oraz pierwszy komputer elektroniczny. W Europie wynaleziono polimery oraz telewizję. Nauczono się stosować aerozole, odkryto penicylinę, zbudowano pierwszy radar oraz skonstruowano silnik odrzutowy. Naukowcy Trzeciej Rzeszy zbudowali pierwszą rakietę potrafiącą wylecieć w kosmos (V2). Druga wojna światowa zrewolucjonizowała dotychczasową strategię. Zastosowanie niekonwencjonalnych rozwiązań jak bomby atomowe stanowiło milowy krok i nową epokę w historii wojskowości, której omówienie było tematem wielu artykułów, badań oraz esejów (Murray, Millet 1996, s. 15 i n.).

Okres powojenny, w którym zarysował się świat podzielony na dwa główne obozy, to czas ponownego spowolnienia wynalazczości. Można jednak wyróżnić ówczesne cztery najważniejsze wynalazki, to jest tranzystor, sztucznego satelitę, silnik wewnątrzobrotowy oraz laser. Następnym kryzysem jaki przyszedł, był ten związany z tak zwanymi kryzysami naftowymi, które w ostateczności doprowadziły do upadku krajów o gospodarce centralnie planowanej. Lata 70-te i 80-te to okres licznych innowacji w elektronice i technologiach komputerowych. Przeważająca ich część wynaleziona została w USA, a zaliczyć do nich można mikroprocesor, Internet, komputer osobisty, wahadłowiec, laptop, witryny internetowe, w tym portale społecznościowe, oraz teleskopy kosmiczne. W Szwecji wynaleziono telefon komórkowy, zaś w Holandii płytę kompaktową. Technologie satelitarne przyczyniły się do zastąpienia konwencjonalnych technik wywiadowczych. Ulepszone uzbrojenie, technologie ponaddźwiękowe, a także innowacje w medycynie i robotyce sprawiły, że pomiędzy siłami zbrojnymi krajów wysokorozwiniętych a pozostałymi wytworzyła się niebywała przepaść technologiczna. 
Po upadku komunizmu nastąpił okres dynamicznego rozwoju. Jak wykazano, nie było wtedy intensywnej innowacyjności. Jedynym wartym uwagi wynalazkiem jest klonowanie. Początek obecnego kryzysu zwanego zadłużeniowym również nie przyniósł jeszcze głośnych innowacji. Jedynie odkrycie antymaterii oraz ostatnie doświadczenia z teleportacją budzą nadzieję na poprawę.

Jak widać okresy względnej niestabilności sprzyjały intensyfikacji działań na rzecz innowacyjności. Powstaje zatem pytanie, jaka jest prawidłowość, czy wojny i armie są wyłącznie beneficjentami nauki, czy też sprzyjają rozwojowi naukowemu? To, że naukowe osiągnięcia służą poprawie i ulepszaniu techniki wojennej i bezpieczeństwa narodowego, wydaje się aktualne i oczywiste. Jednakże przemysł zbrojeniowy i konieczność stania na straży bezpieczeństwa narodowego przez państwo sprawia, że armia, przemysł zbrojeniowy i państwo stają się również jednymi z głównych mecenasów nauki (Zarzecki 2002, s. 73-77). Ta prawda, choć nie tak oczywista, wydaje się po przeanalizowaniu historii wynalazczości potwierdzona. Kierunek zwrotny na linii świat nauki - świat wojska, przyjęły liczne wynalazki, których opracowanie wiązało się z rozwojem technologii wojennej, a zastosowanie miało charakter cywilny. Na przykład wcześniej przytoczony semafor. Zastosowanie go na polach bitew, przyniosło korzyści w ówczesnej komunikacji, ale także pozwoliło zastosować ten wynalazek w kolejnictwie, a doszło wręcz do tego, że współcześni kierowcy, korzystając z semaforów na skrzyżowaniach zaczynają coraz częściej zwracać uwagę, że jest ich za wiele. Lokalne władze często dążą do maksymalizacji bezpieczeństwa na drogach kosztem płynności ruchu. Ta sama kolej rzeczy miała się z wynalazkiem telegrafu i alfabetu Morse'a - oba posłużyły w celach cywilnych do usprawnienia komunikacji. Kolejny przykład to morfina, opracowana na potrzeby szpitali polowych, karierę zrobiła również w ratowaniu od bólu nie tylko żołnierzy. Eksperymenty z pociskami fosforowymi, mającymi za zadanie wzniecać pożary na ówczesnych, jeszcze drewnianych okrętach, pozwoliły na opracowanie tak użytecznego wynalazku jakim są zapałki (Dyskant 1983, s. $171 \mathrm{i}$ in.). Mechanizm zastosowany przez Samuela Colta w rewolwerach dziś powszechnie stosowany jest także w specjalnych maszynach służących butelkowaniu napojów. Rozwój technologii związanych z powstaniem okrętów podwodnych umożliwił eksplorację dna mórz i oceanów. Dzięki temu nie tylko możemy zafundować sobie wycieczki po rafach koralowych, ale przede wszystkim czerpać z dna cenne dla gospodarki surowce, jak ropę naftową. Wiele wynalazków związanych z wojnami światowymi również spowodowało ogromny rozwój w przemyśle. Przykładem może być wynalazek karabinu maszynowego. Masowe zużycie amunicji spowodowało ogromne zapotrzebowanie na wyroby przemysłu metalowego. W okresie wojny i powojennym, można było obserwować ogromny postęp w metalurgii, zarówno stali jak i stopów (jak mosiądz). Nowe techniki wytopu i obróbki metali zapewne nie byłyby potrzebne, gdyby nie zapotrzebowanie przemysłu zbrojeniowego i pojawiły by się później. Budowa sterowców i ich szerokie zastosowanie w czasach I wojny światowej, a także zastosowanie lotnictwa i doświadczenia pilotów wojskowych wniosły wiele do rozwoju lotnictwa cywilnego. Wynalezienie rakiety w okresie międzywojennym pozwoliło na rozwój technologii kosmicznych i poszerzyło horyzonty ludzkości. Kolejny wynalazek, jakim jest radar, to odkrycie, bez którego dziś nie mielibyśmy telefonii komórkowej oraz wielkich teleskopów. Wynalezienie silników odrzutowych mających dać przyspieszenie samolotom bojowym końcówki II wojny światowej pozwoliło usprawnić komunikację powietrzną i dziś w ciągu doby możemy przemierzyć cały świat. Zastosowanie teflonu, dziś kojarzące się większości głównie z pokryciem patelni, po- 
czątkowo miało miejsce w amunicji, a także w materiałach opatrunkowych. Również reaktor atomowy, powstały w wyniku eksperymentów prowadzonych nad rozszczepieniem jąder atomowych i wyzwoleniem ich energii, co było potrzebne do konstrukcji bomby atomowej, przyczynił się do wytworzenia wielu terawatogodzin energii elektrycznej napędzającej niejedną gospodarkę w sposób ekologiczny. Systemy szyfrujące stosowane w czasie II wojny światowej, na przykład słynna Enigma, dały początek komputerom. Współcześnie mało kto pamięta, że Internet został również wynaleziony przez wojskowych. Bez niego nie byłoby dziś stron internetowych czy uwielbianych i uzależniających wręcz portali społecznościowych. Dynamika rozwoju technik szpiegowskich w czasie tzw. Zimnej Wojny doprowadziła do wysłania pierwszych satelitów szpiegowskich w kosmos (Świątnicki 1990, s. 301 i in.). Technologia zastosowana $\mathrm{w}$ ich konstrukcji okazała się pożyteczna w budowie stacji i teleskopów kosmicznych oraz sond, dzięki którym nastąpił w ostatnich latach ogromny postęp w poznawaniu kosmosu (Rosen 1988). Te przykłady unaoczniają znaczenie sektora zbrojeniowego we współczesnej nauce. Mimo delegalizacji wojny traktatami międzynarodowymi, jest i raczej pozostanie ona jednym z naturalnych, ludzkich rozwiązań różnych problemów. Można się z tym nie zgadzać, można się też z tym pogodzić. To zależy od osobistych poglądów. Obiektywnie, jest ona mimo wszystko obecna na świecie i po II wojnie światowej nie było żadnego roku, w którym gdzieś na świecie nie trwały walki (Brito, Intiligator 1981, s. 41-57).

\section{ZRÓŻNICOWANIE BADAŃ W PRZEMYŚLE ZBROJENIOWYM I OBRONNOŚCI}

W związku z powyższym, że wojny w które każdy kraj może być zaangażowany są rozmaite, od konwencjonalnych, po asymetryczne, partyzanckie, z zastosowaniem BMR, elektroniczne i sieciowe, wywiadowcze, a w przyszłości pewnie także kosmiczne (Münkler 2004), różne mamy na świecie rodzaje wojsk. Każda forma walki, a także potrzeby wojska, mają odpowiadające im inne dziedziny naukowe, w których odpowiednie instytuty wojskowe prowadzą badania (Kardasz 2010, s. 8).

Ogólnie dzielimy wojska na lądowe, morskie i powietrzne. W każdej z tych kategorii wyróżnić można poszczególne typy wojsk, a każde z nich korzysta i rozwija swoje rozwiązania technologiczne (Sułek 2008, s. 72). Inne, różnorodne prace są prowadzone przez zakłady obsługujące potrzeby rodzajów wojsk lądowych: wojsk obrony terytorialnej (w tym oddziałów zwiadowczych, żandarmerii, sztabów mobilizacyjnych i uzupełnień, czy oddziałów zaopatrzenia i łączności oraz polowe oddziały medyczne) (Jakubczak 2002, s. 22), wojsk chemicznych, inżynieryjnych (saperów, oddziałów desantowo-przeprawowych, czy drogowo-kolejowych), artylerii i wojsk rakietowych, w tym obrony przeciwlotniczej i antyrakietowej, wojsk pancernych (Forty 2009), piechoty zmechanizowanej (innej prawie nie używa się już w nowoczesnych zawodowych siłach zbrojnych) (Dąbrowski, Grobelny 2007, s. 2-12) oraz kawalerii (używana wciąż w krajach, gdzie istnieją duże trudnodostępne tereny dla transportu kołowego - pustynie, busz, oraz w krajach posługujących się kawalerią jako policją np. Sudan).

Inne technologie mają zastosowanie i rozwijają się dzięki istnieniu floty. Zupełnie inne rodzaje wojsk potrzebują nieraz zupełnie innego rodzaju wiedzy do zastosowania. Jest tu 
też obrona cywilna, jej specjalny rodzaj - oddziały ochrony wybrzeża, mamy także oddziały inżynieryjno-stoczniowe, odpowiednik lądowych sił inżynieryjnych, jednak różniący się nieco, gdyż zawiera flotę minersko-saperską, jest także piechota morska, a zatem niektóre technologie wykorzystywane w wojskach lądowych mają również zastosowanie we flotach. Głównym trzonem sił morskich jest jednak marynarka składająca się z okrętów wojennych i transportowych. Te pierwsze można podzielić na trzy różniące się od siebie grupy, to jest: okręty podwodne, oraz nawodne, oraz flotylle śródlądowe, które mają jeszcze inny charakter. Każdy z okrętów może pełnić inne funkcje, co dodatkowo komplikuje podział (Makowski 2000, s. 28 i n.).

Również w lotnictwie mamy jednostki naziemne, broniące lotnisk i je obsługujące (oddziały radiolokacyjne, remontowo-lotniskowe), ale poza tym głównym trzonem sił powietrznych są myśliwce i bombowce oraz lotnictwo transportowe. Ponadto jest jeszcze tzw. kawaleria powietrzna, czyli śmigłowce. Jak widać we współczesnych siłach zbrojnych jest spora różnorodność (Spalding 2009, s. 3-9).

Dodać do tego jeszcze można rodzaje sił zbrojnych powstających poza oficjalnymi siłami zbrojnymi państw. Są to oddziały partyzanckie, najemne, piracko-bandyckie, czy terrorystyczne, oraz różnego rodzaju doraźne milicje obywatelskie. Trudno jednak mówić, by prowadziły one różnego rodzaju badania naukowe.

Poza siłami zbrojnymi, przemysł zbrojeniowy rozwija technologie także dla wywiadu i kontrwywiadu. Wszystkie branże przemysłu zbrojeniowego, produkujące i opracowujące technologie na potrzeby wyżej wskazanych rodzajów wojsk mają do dyspozycji w każdym większym kraju odpowiednie instytuty badawcze. W Polsce jest to na przykład WAT (Wilczyński 2011, s. 20-33). Nie należy jednak mylić tych instytutów z ośrodkami kształcącymi kadry, jak AON, AMW i inne wyższe szkoły oficerskie i wojskowe.

\section{INNOWACJE W PRZEMYŚLE ZBROJENIOWYM I OBRONNOŚCI W OSTATNICH LATACH}

Ostatnia cześć niniejszego artykułu przedstawia wynalazki opracowane w różnych instytucjach badawczych pracujących na potrzeby wojska, przemysłu zbrojeniowego i obronności. W ostatnich pięciu latach, jak i w ogóle w dziesięcioleciach, przyrost wiedzy na różne tematy i zagadnienia jest ogromny. Również rozwój technologii wojennych nie odchodzi od tego trendu. Do najszybciej rozwijających się pod tym względem krajów należą Stany Zjednoczone. Większość patentów sektora zbrojeniowego wywodzi się z ośrodków badawczych tego mocarstwa.

Zaczynając od 2005 roku, w przemyśle zbrojeniowym największą sławą okrył się wynalazek zwany w USA Persistent Threat Detection System - Stały System Wykrywania Zagrożeń. Tani sposób na wykrywanie aktywnych walk oraz utrzymanie stałej łączności - zdalny sterowiec naszpikowany nowoczesnymi urządzeniami telekomunikacyjnymi i detektorami wystrzałów. Drugi wynalazek to osobisty wykrywacz ładunków wybuchowych. Jest to niewielkie 3-kilogramowe urządzenie wykrywające obecność 90\% substancji wybuchowych. Robi to tak samo skutecznie jak przeszkolony pies.

Rok 2006 zaowocował patentem znanym w Ameryce jako Blow Torch Counter-IED System. Nazwę tę nosi urządzenie służące do detonacji min przydrożnych i kierowania od- 
rzutu eksplozji poza pojazd. Sprzęt idealny do ochrony konwojów przed przydrożnymi minami. W 2006 roku opatentowano również zdalny system monitoringu miejskiego. Działa on w oparciu o program komputerowy wychwytujący sygnały z sieci Internet, kamer miejskich, satelitów i sieci telefonii komórkowej, automatycznie informujący operatora o zagrożeniach. Jego pierwsze testy pokazały, że możliwości jego zastosowania są ogromne i rosną wprost proporcjonalnie do osiągów najnowszych komputerów.

Największą innowacją roku 2007 było wprowadzenie w armii amerykańskiej „Damage Control Resuscitation of Severely Injured Soldiers", czyli najnowszej metody resuscytacji najciężej rannych. Oprócz zmiany kilku kroków postępowania resuscytacyjnego, zmieniła się substancja podawana rannym zamiast krwi i osocza. Mieszanka tych dwóch składników wzbogacona została o substancje zapobiegające szokowi i utracie ciśnienia. Szpitale cywilne w USA już wprowadzają go w życie.

W kolejnym 2008 roku wprowadzono innowację z zakresu robotyki. Jest nią zdalna wieżyczka strzelecka, która zastępuje do tej pory najbardziej ryzykującego życiem operatora karabinu maszynowego na pojeździe opancerzonym. Widząca z dużą ostrością, bezpieczna, choć kosztowna jednostka zdolna do walki w warunkach dnia i nocy (kamera podczerwona) gotowa do zainstalowania na dowolnym pojeździe może okazać się krokiem w stronę całkowitej robotyzacji wojny.

Rok 2009 był dla wielu analityków i obserwatorów innowacji w świecie zbrojeń zaskakujący. Pojawiły się bowiem dwa wynalazki, które można określić jako przełomowe. Pierwszym jest rakieta Ares. Wojenny pocisk balistyczny, który poradzi sobie z wielotonowym ładunkiem. Będzie on jednak przede wszystkim wykorzystywany nie do celów wojennych, jak przenoszenie głowic atomowych. Rakieta ta ma przede wszystkim służyć w NASA jako nośnik ciężkich ładunków na orbitę, a nawet poza nią. Nie tylko chodzi tu o satelity szpiegowskie i broń kosmiczną różnego rodzaju, ale również aparaturę naukową. Wielu uważa, że jest to krok ku masowej kolonizacji kosmosu przez USA. Drugi wynalazek to okiełznanie owadów. Stworzenie owadów cyborgów przez wczepienie im mikroskopijnego urządzenia mającego nad nim całkowitą kontrolę sprawiło ogromną niespodziankę. Kontrola mózgów owadów przez mały chip jest krokiem do stworzenia zwierzęcych armii sterowanych bezprzewodowo. Dzięki zastosowanej technologii można kontrolować ich ruch komputerem.

W poprzednim roku żaden z wynalazków nie uzyskał tak dużego nagłośnienia jak te z 2009 roku. Można jednak podkreślić, iż do innowacji dość użytecznych i zasługujących na wyróżnienie zalicza się egzoszkielet oraz X-flex. Egzoszkielet to inaczej szkielet zewnętrzny. Prace nad ultralekkim szkieletem wspomagającym ruch osób częściowo sparaliżowanych pozwoliły przywrócić nadzieję wielu przykutym do łóżek i wózków. Tajemniczo brzmiąca nazwa X-flex określa nowy rodzaj pancernej tapety. Podobny do kevlaru materiał po przyklejeniu do ścian staje się od nich mocniejszy i skutecznie chroni przed ogniem, szrapnelami, wybuchami jak i skutkami trzęsień ziemi (na podstawie „Defense Industry Daily” - www. defenseindustrydaily.com).

Obecny rok również przyniesie sporo wynalazków. Z aktualnych doniesień wynika, że w Polsce opracowano nowoczesny model bezzałogowego samolotu taktycznego. Jego zaletą nie jest skuteczność bojowa, lecz niezawodność, duża użyteczność oraz tanie koszty produkcji. Z zagranicy dochodzą też słuchy o próbach z teleportacją. Na razie potwierdzono, iż udało się przenieść jeden atom o metr. Odkrycie skutecznego sposobu teleportacji byłoby 
przełomowe dla ludzkości. Co przyniosą prace nad tym wynalazkiem, tego na razie jeszcze nie wiemy.

Podsumowując - bardzo szybki rozwój technologii wojskowych i badań nad wykorzystaniem nowoczesnych wynalazków w zbrojeniach w poprzednich dekadach przyniósł również rozwiązania dla cywilów w ich codziennym życiu. Zbrojenia i militarnie uwarunkowane badania nie tylko pomagają zabezpieczyć państwo, ale także pozwalają na wprowadzenie nowych wynalazków dla całych społeczeństw i dostarczają znacznej części ważnych innowacji dla cywilnych spółek korzystających z nowoczesnych technologii.

\section{Literatura}

Brito D.L., Intriligator M.D., 1981, Strategic arms limitation treaties and innovations in weapons technology, "Publich Choice", vol. 37 (1).

Dąbrowski Cz., Grobelny Z., 2007, Zmiany w strukturach, uzbrojeniu i sposobach prowadzenia dziatań taktycznych na przełomie XX $i$ XXI wieku w wybranych państwach NATO, „Zeszyty Naukowe WSOWL", nr 1 (143).

Dyskant J.W., 1983, Konflikty i zbrojenia morskie 1918-1939, Wydawnictwo Morskie, Gdańsk.

Forty G., 2009, Nowoczesne czotgi, Bellona, Warszawa.

Jakubczak R., 2002, Wojska obrony terytorialnej: militarne bezpieczeństwo Rzeczypospolitej Polskiej u progu trzeciego tysiaclecia, Bellona, Warszawa.

Kardasz R., 2010, Wspótpraca między wojskiem a przemystem z punktu widzenia spótki przemystu obronnego, Konferencja Stowarzyszenia Euro-Atlantyckiego: „Pieniądze dla armii zamówienia dla firm", MSPO, Kielce.

Liebfeld A., 1975, Arcykapłani zbrojeń: z dziejów handlarzy i fabrykantów broni, Śląsk, Katowice.

Makowski A., 2000, Siły morskie współczesnego państwa, Impuls Plus Consulting, Gdynia.

Murray W., Millet A.R. (red.), 1996, Military Innovation in the Interwar Period, Cambridge University Press, Cambridge.

Münkler H., 2004, Wojny naszych czasów, Wyd. WAM, Kraków.

Parker G., 1988, The military revolution: military innovation and the rise of the West, 1500-1800, Cambridge University Press, Cambridge.

Rosen S.P., 1988, New Ways of War: Understanding of Military Innovation, "International Security", vol. 13 (1).

Spalding R., 2009, America’s two Air Forces, “Air \& Space Power Journal”, vol. 23 (2).

Sułek M., 2008, Programowanie gospodarczo-obronne, Bellona, Warszawa.

Świątnicki W., 1990, Wojna w kosmosie?, Wyd. MON, Warszawa.

Wilczyński P.L., 2010, Terytorium w myśli strategiczno-wojskowej, „Przegląd Geopolityczny”, vol. 2.

Wilczyński P.L., 2011, Warfare \& peace research on universities, "Brazilian Geographical Journal", vol. 2, n. 1.

Zarzecki T.W., 2002, Arms diffusion: the spread of military innovation in the international system, Routledge, New York.

\section{Strony internetowe}

www.defenseindustrydaily.com 


\section{Armament and national defence innovations as technological advances accelerator}

Contemporary computer models and strategic simulators often suggest that technological advantage is the key in economical and geopolitical success of states. The overwhelming advancement in military research and technology in previous decades brought great inventions to the civilians and everyday life, due to the utilitarian approach of modern societies. The first section of this study presents a historical view on innovations, and reveals that during periods of economical and political instability, especially wars, the rate of technological development was hastened two or three times, compared to periods of peace and prosperity. The second section presents examples of technological innovations in the military sector and its civilian applications. The results of the study show that, although wars decrease economic strength of states, crisis and development in the military sector has positive impact on their innovations and technological advancement. Thus, military funding of research not only helps to secure statehood, but also makes new inventions available for whole societies, and provides a substantial, remarkable support for civilian companies which use advanced technologies.

Mgr Piotr L. Wilczyński

Uniwersytet Pedagogiczny, Kraków

Instytut Geografii

e-mail: p.wilczynski@geostrategic.pl 